\title{
THE MODELING AND MEASUREMENT OF THE DEFORMATION OF A SLOPING SNOW-PACK
}

\author{
By Theodore E. Lang \\ (Department of Engineering Mechanics, Montana State University, Bozeman, Montana 597I5, \\ U.S.A.)
}

and Richard A. Sommerfeld

(U.S. Department of Agriculture Forest Service, Rocky Mountain Forest and Range Experiment Station, Fort Collins, Colorado 8052 I, U.S.A.)

\begin{abstract}
The modeling of deformation in snow-pack of realistic geometry is reported. Experimentally measured deformation rates are compared with corresponding rates predicted from a finite-element model developed using local stratigraphy in the experimental area. Specifically designed deformation gages placed on an avalanche-sensitive snow slope at Berthoud Pass, Colorado, during the winter of 1972-73, were used to measure the experimental values. The finite-element code, based upon a plane-strain idealization, was used to model the steady-state flow of the slope. The program incorporates visco-elastic properties of the snow-pack, snow-layer stratigraphy, and the orthotropic properties of snow when both tension and compression components of stress act at a point. The degree of correlation between experimental and computed values of deformation rates is reported, and limitations of the analysis in conjunction with the type of experimental data taken are discussed.

RÉsumÉ. Modèlisation et mesure de la déformation d'un manteau neigeux sur une pente. On rapporte la modèlisation de la déformation d'un manteau neigeux en grandeur réelle. Les vitesses de déformation mesurées expérimentalement sont comparées avec les vitesses correspondantes prévues à partir d'un modèle aux éléments finis construit en utilisant la stratigraphie locale dans la zone d'expérience. Des jauges de déformation spécialement conçues placées sur une pente de neige sujette aux avalanches au Berthoud Pass (Colorado) au cours de l'hiver 1972-73 ont permis de mesurer les valeurs expérimentales. Le code aux éléments finis, basés sur une schématisation des déformations dans un plan a servi pour reproduire l'écoulement permanent sur la pente. Le programme incorpore les propriétés viscoélastiques linéaires du manteau neigeux, la stratigraphie des couches de glace et les propriétés orthotropiques de la neige lorsque les composantes de traction et de compression agissent ensemble en un point. On rapporte le degré de corrélation entre les valeurs calculées et expérimentales de la vitesse de déformation et on discute les limites de l'analyse en égard au type de données expérimentales utilisées.

Zusammenfassung. Modellbildung und Messung der Verformung einer geneigten Schneedecke. Es wird über eine Modellvorstellung für die Verformung einer Schneedecke unter Berücksichtigung der tatsächlichen Geometrie berichtet. Experimentell gemessene Verformungsraten werden mit entsprechenden Raten verglichen, die aus einem Modell mit finiten Elementen für die lokale Stratigraphie im Versuchsgebiet hergeleitet sind. Zur Messung der Feldwerte wurden eigens konstruierte Verformungsmessdosen im Winter 1972/73 auf einem lawinenverdächtigen Schneehang am Berthoud Pass, Colorado, verteilt. Der stationäre Fluss auf dem Hang wurde unter der Modellvorstellung für finite Elemente, idealisiert mit der Annahme eines ebenen Spannungszustandes, hergeleitet. Das Programm erfasst die lineare visko-elastischen Eigenschaften der Schneedecke, die Stratigraphie der Schneeschichten und die orthotropischen Eigenschaften des Schnees, wenn sowohl Zug- wie Druckspannung an einem Punkt angreifen. Der Úbereinstimmungsgrad zwischen den gemessenen und berechneten Werten der Verformungsrate wird angegeben; die Grenzen, die der Analyse durch die Art der Versuchsdaten gesetzt sind, werden diskutiert.
\end{abstract}

\section{INTRODUGTION}

In the progression of analyses of steeply sloping snow-packs, emphasis has been placed upon the state of stress in attempts to understand the mechanisms leading to avalanche release. Haefeli ( 1963 ) hypothesizes a material transformation based upon change of the axes of principal stress with depth leading to deep slab failures. Perla (I97I) develops a proof of the existence of a weak basal plane as a prerequisite for avalanche release, drawing upon the observed characteristics of the crown-region fracture geometry, and the associated stress distribution. Smith and Curtis ([1975]) demonstrate the applicability of numerical methods to slab analysis, and model stress distribution and failure prediction based upon material layering and local geometric effects. A first attempt at deformation prediction was made by Lang and Brown ([1975]) in which a nominal visco-elastic material idealization is used in 
conjunction with an assumed shear weakness in the basal plane to predict stress and strain-rate distributions theoretically. The present work is the next logical step in continued analysis of steep snow-packs. Analytically predicted snow-pack deformations are compared to actual measured deformations obtained by use of strain gages mounted in creeping snow-packs.

The ability to represent the deformation state of snow-pack analytically, a more difficult task than stress prediction, opens numerous possibilities for greater understanding of the avalanche problem. For example, correlation with developing theories of the incidence and geometry of failure planes, strain-rates for fracture, influence of weak layers on creep, and other phenomena of snow creep becomes feasible.

Snow-packs in avalanche paths have irregular surfaces of contact with the ground, are layered, and exhibit large variation in specific weight with attendant large variations in material properties. Snow is also orthotropic in the sense of exhibiting different material properties in tension and compression. Complexities of this sort are readily handled by the finite-element method, which makes this technique a logical choice for snow-pack modeling.

In this paper the authors report the following: (I) the construction of a finite-element analytical model; (2) a careful estimation of material properties from available data; (3) the first results from an extensive deformation-measuring program; and (4) a detailed comparison between the modeled and measured deformations.

The instrumentation used in the field studies has been described by Sommerfeld ([1975]). The deformation measurements were made during the course of three winters at Berthoud Pass, Colorado. In this paper we use the results of the first $25 \mathrm{~d}$ of measurements in which the positions of four points in the snow-pack were monitored. The analysis can be viewed as a pilot study to determine the feasibility of modeling deformation of sloping snow-packs.

\section{THE FINITE-ELEMENT MODEL}

A finite-element model is constructed which incorporates the plane-strain idealization, proportionality between stress and strain-rate (steady state) and a representation of material orthotropy. An efficient computer code that contains these features is completely documented by Goudreau and others (1967). It is adapted for use on the CDC 7400 computer in order to carry out the calculations presented here. The computer code accepts a maximum of 25 different material descriptions, which is the principal limitation in application to the slope deformation problem.

The model geometry is derived from the experimental geometry but is not an exact duplication. The layers of the model do not necessarily correspond to the measured snow layering, primarily because of the material limitation noted above. Therefore, specific weight and secondary creep-rate coefficients are linearly weighted in the proportion of each experimental layer thickness in each finite element (compare Figure I with Figure 2).

Three different periods are modeled. A pre-storm period, days $35^{\circ}$ to $35^{2}$, I972, is modeled with a five-layer model (Fig. I) ; a storm period, days 353 to 357 , is modeled with a sevenlayer model; and a post-storm period, days oor to 005, i973, is modeled also with the sevenlayer model.

For stress evaluations, local geometry variations are not of extreme importance. However, it was found that the detailed geometry of the snow-ground surface has a pronounced effect on the deformations. A surface with four constant-slope segments proved inadequate. The gradually changing slope geometry which was adopted as shown in Figure I, significantly reduces numerical perturbations. Gradual changes in material properties along the layers proved also to be necessary to eliminate large deformation perturbations between successive elements. This requirement for gradual changes in specific weight resulted in the use of many more material specifications than originally anticipated. 


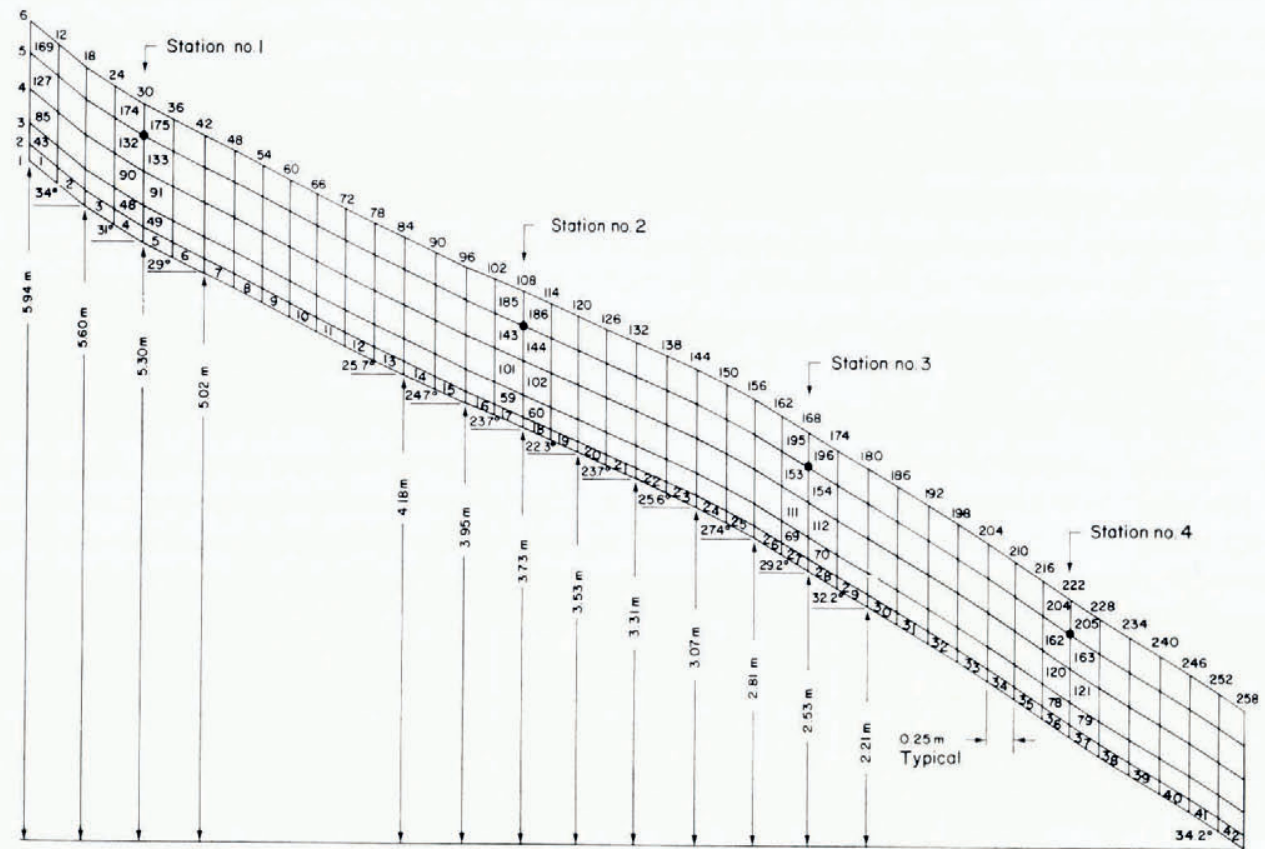

Fig. I. Detail of slope geometry and finite-element representation.

Snow has different material properties in tension and compression (Shinojima, 1967) which can be represented by assuming local material orthotropy. However, prior to evaluation, the distribution of tension and compression components is not known, so an iterative procedure is used to account for this orthotropy. The stress in all finite elements is computed using a totally compressive material description. The material description is then modified based upon the tensile components obtained. The stresses are recomputed based upon this up-date, and the cycling continued until sufficient agreement is achieved. After three or four iterations of this type, the local angles of orthotropy, which are used as an index of convergence, tend toward constant values.

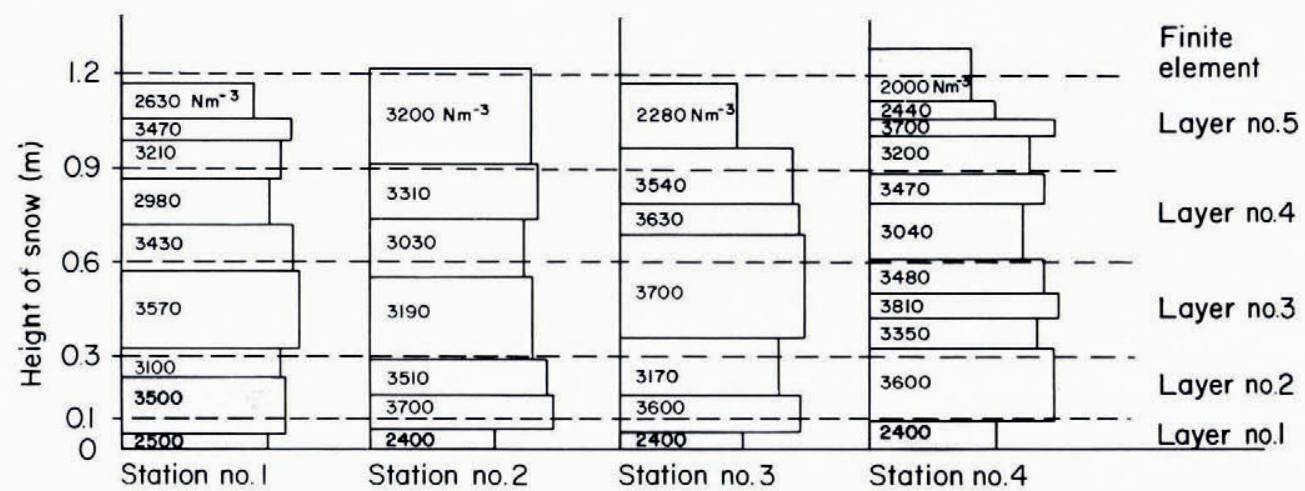

Fig. 2. Specific weight of snow versus height at the four gaging stations, with superimposed levels of finite-element layering as indicated. Data for day 347, 1972. 
Output from the computer code includes components of steady-state deformation rates at each grid point, stress components and corresponding strain-rate components for each element, the local angle of orthotropy, and the internal energy rate.

\section{MATERIAL REPRESENTATION}

The material representation for snow should account for both volumetric and deviatoric components of deformation. For each of these mechanisms of deformation a four-element Burgers-body representation is assumed in which stress is related to strain by

$$
\left(P_{2} \frac{\partial^{2}}{\partial t^{2}}+P_{1} \frac{\partial}{\partial t}+\mathrm{I}\right) \sigma=\left(q_{2} \frac{\partial^{2}}{\partial t^{2}}+q_{1} \frac{\partial}{\partial t}\right) \epsilon .
$$

In this general form of the equation $\sigma$ and $\epsilon$ may be either the dilatational or deviatoric components of stress and strain respectively. Proceeding with the standard process of taking the Laplace transform and retaining only the steady-state response to a step input of stress, the components of strain-rate are found to be related to the stresses, in a plane-strain representation, by

$$
\left\{\begin{array}{c}
\dot{\epsilon}_{x} \\
\dot{\epsilon}_{y} \\
\dot{\epsilon}_{x y}
\end{array}\right\}=\left[\begin{array}{ccc}
C_{2} & -C_{4} & 0 \\
-C_{4} & C_{2} & 0 \\
0 & 0 & C_{6}
\end{array}\right]\left\{\begin{array}{c}
\sigma_{x} \\
\sigma_{y} \\
\tau_{x y}
\end{array}\right\} .
$$

Details of the derivation leading to Equation (2) are outlined in a paper in preparation*. In Equation (2)

$$
C_{2}=\frac{3 K+4 \mu}{4 \mu(3 K+\mu)}, \quad C_{4}=\frac{3 K-2 \mu}{4 \mu(3 K+\mu)}, \quad C_{6}=\frac{\mathrm{I}}{2 \mu},
$$

where $K$ and $\mu$ are the bulk modules and shear viscosity for snow respectively. Separate values for these constants must be established for snow in compression and tension. To establish values for $K$ and $\mu$, results by Shinojima (1967) and by Lang and Brown ([1975]) are used for the compression relationships, namely,

$$
\frac{\mathrm{I}}{C_{2}}=5.85 \times 1 \mathrm{I}^{2} \exp \left(25.3 \gamma+9.5^{8} \times \mathrm{IO}^{-2}|T|\right),
$$

and

$$
\frac{2 \mu}{{ }_{3} K}=0.47,
$$

where $\gamma$ is the specific weight of the snow and $T$ is the Celsius snow temperature. The corresponding relationships for tension are derived from results by Shinojima $(1967)$ and by Salm ([r975]), namely,

$$
\frac{\mathrm{I}}{C_{2}}=9.93 \times \mathrm{IO}^{2} \exp \left(25.3 \gamma+9.5^{8} \times 10^{-2}|T|\right),
$$

and

$$
2 \mu / 3 K=0.27
$$

where these equations are applicable for applied stresses less than $8000 \mathrm{~N} \mathrm{~m}^{-2}$. It is noted from Equations (4) and (5), by virtue of the relative magnitude of the amplitude coefficients, that separate accounting of principal tensile and compressive axes in the material representation introduces a significant difference in material viscosity. By solving Equations (4)

* Sommerfeld, R. A., and Lang, T. E. Deformation of a sloping snowpack. Rocky Mountain Forest and Range Experiment Station, Fort Collins, Colorado. 
and (5) for $K$ and $\mu$ and substituting these values into Equation (2), separate constitutive equations for snow in tension or compression can be established. To represent the case of combined tension and compression components at a point, we start with the three-dimensional orthotropic material law, which for tension along the $x$ axis and compression along the $y$ and $z$ axes, is

$$
\left\{\begin{array}{c}
\epsilon_{x} \\
\epsilon_{y} \\
\epsilon_{z}
\end{array}\right\}=\left[\begin{array}{lll}
\frac{\mathrm{I}}{E_{\mathrm{T}}} & -\frac{\nu_{\mathrm{C}}}{E_{\mathrm{C}}} & -\frac{\nu_{\mathrm{C}}}{E_{\mathrm{C}}} \\
\frac{\nu_{\mathrm{T}}}{E_{\mathrm{T}}} & +\frac{\mathrm{I}}{E_{\mathrm{C}}} & -\frac{\nu_{\mathrm{C}}}{E_{\mathrm{C}}} \\
\frac{\nu_{\mathrm{T}}}{E_{\mathrm{T}}} & -\frac{\nu_{\mathrm{C}}}{E_{\mathrm{C}}} & +\frac{\mathrm{I}}{E_{\mathrm{C}}}
\end{array}\right]\left\{\begin{array}{c}
\sigma_{x} \\
\sigma_{y} \\
\sigma_{z}
\end{array}\right\} .
$$

Introducing the condition of plane strain $\left(\epsilon_{z}=0\right)$ and noting the correspondence

$$
\left.\begin{array}{l}
\nu \rightarrow C_{4} / C_{6}, \\
E \rightarrow \frac{\mathrm{I}+\nu}{C_{6}},
\end{array}\right\}
$$

the modified constitutive law relating strain-rate to stress, for steady-state response, is

$$
\left\{\begin{array}{c}
\dot{\epsilon}_{x} \\
\dot{\epsilon}_{y} \\
\dot{\epsilon}_{x y}
\end{array}\right\}=\left[\begin{array}{ccc}
C_{2}{ }^{M} & -C_{4}{ }^{M} & 0 \\
-C_{4}{ }^{M} & C_{2}{ }^{M} & 0 \\
0 & 0 & C_{6}{ }^{M}
\end{array}\right]\left\{\begin{array}{c}
\sigma_{x} \\
\sigma_{y} \\
\tau_{x y}
\end{array}\right\},
$$

where

$$
C_{2}{ }^{\mathrm{M}}=\frac{\mathrm{I}}{E_{\mathrm{T}}}\left(\mathrm{I}-\nu_{\mathrm{T}} \nu_{\mathrm{C}}\right), \quad C_{4}{ }^{\mathrm{M}}=\frac{\nu_{\mathrm{C}}}{E_{\mathrm{C}}}\left(\mathrm{I}+\nu_{\mathrm{C}}\right), \quad C_{6} \mathrm{M}=\frac{\left(\mathrm{I}+\nu_{\mathrm{C}}\right)^{\frac{1}{2}}\left(\mathrm{I}+\nu_{\mathrm{T}}\right)^{\frac{1}{2}}}{\left(E_{\mathrm{T}} E_{\mathrm{C}}\right)^{\frac{1}{2}}} .
$$

The coefficients in Equations (9) are not independent, but are subject to the reciprocity relationship of linear orthotropy that $\nu_{\mathrm{T}} E_{\mathrm{C}}=\nu_{\mathrm{C}} E_{\mathrm{T}}$. By restricting attention to steady-state response, Equation (8) contains constant coefficients only, so that a computer code set up for elastic equations can equally well be applied to secondary-creep calculations by using the coefficients of Equation (8) rather than elastic coefficients.

\section{EXPERIMENTAL PROGRAM}

Three types of gage were designed to be placed in the snow-pack: a vertical gage to measure settlement, a slope-parallel gage to measure differential creep, and an angle gage to measure creep angle. The size of the linear gages was based upon the statistical evidence of Sommerfeld ([1975]) that characteristic lengths of $\mathrm{r} .0 \mathrm{~m}$ can be associated with nominal snow properties.

The vertical deformation gages were approximately 1.o m high (Fig. 3). Each gage consisted of a sensing element, an actuation rod, an actuation head, and a protective housing. The sensing element is a linear potentiometer with I $000 \Omega$ total resistance, a linearity of $0.1 \%$, and a total range of $150 \mathrm{~mm}$. The actuation rod ( $12 \mathrm{~mm}$ diameter, aluminum) is attached to the potentiometer at the lower end and to the actuation head (12 $\mathrm{mm}$ wire mesh, o. I $\mathrm{m} \times \mathrm{I} .0 \mathrm{~m}$ rectangle) at the upper end through a swivel joint. The swivel allows rotation between rod and actuation head in the vertical plane, this angle measured by a rotary potentiometer with a total resistance of $\mathrm{I}$ ooo $\Omega$, a linearity of $0.1 \%$ and a range of $90^{\circ}$. 


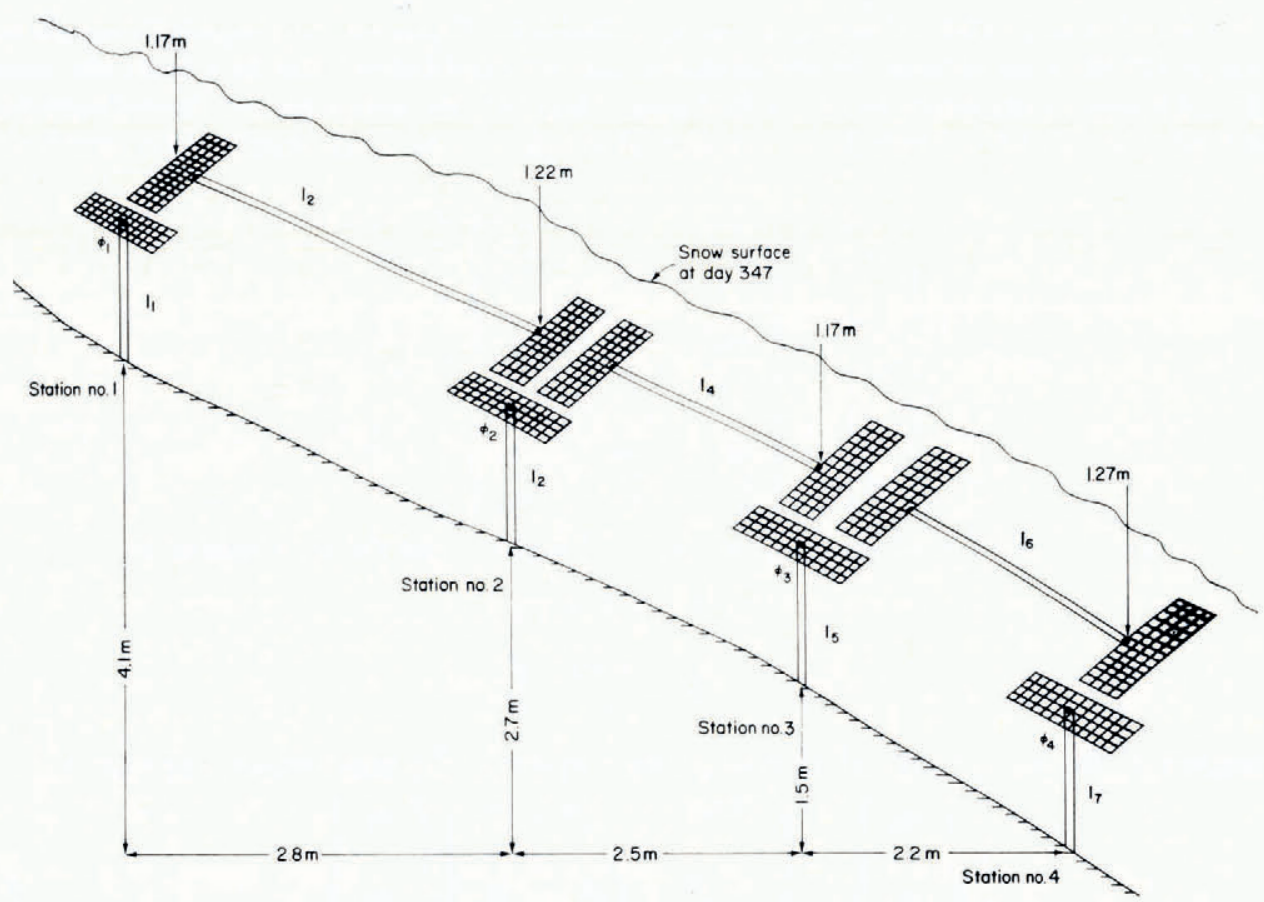

Fig. 3. Deformation-gage notation and geometry in the snow-pack as set on day 34I, 1972.

The $3.0 \mathrm{~m}$ long slope-parallel gages contain the same type of sensing element as the vertical gages. For the slope-parallel gages an actuation head of wire mesh, as above, was attached at each end, and the connecting actuation rods (made from steel to match thermal expansion with that of polycrystalline snow) rode in "Teflon" bearings at each end. The connecting rods were given a slight upward bow so that the rods did not contact the protective housing of the sensors.

Each sensing element formed one half of a bridge circuit, the other half being housed in a heated instrument building about $200 \mathrm{~m}$ away and connected by shielded instrument cable. The bridges were powered by regulated $20 \mathrm{~V}$ d.c. supplies. Sensor outputs were recorded on a slow-speed magnetic tape recorder with a range of $\pm \mathrm{I} .0 \mathrm{~V}$. The bridges were periodically balanced to keep them within the recorder range.

Four vertical gages were installed before the first snow. They were bolted to steel spikes which had been driven into the ground and oriented so that downhill creep loosened the bolts. The plan was for snow to fill in around the gages, but a small avalanche early in the first large storm knocked down the three lowest gages. In resetting these the snow was severely disturbed.

On day 34I, 1972 the gages were installed in approximately $1.0 \mathrm{~m}$ snow. Exact heights and gage designations are shown in Figure 3. The gage outputs were monitored continuously from that time. The slope-parallel gages operated throughout the winter, but the vertical gages reached the ends of their travels at different times. When this happened, the creep (rotation) gages were also adversely affected.

The analog data were digitized and corrected for calibration constants and bridge reset displacements. The final form was in millimeters from initial separation or in degrees from initial angle, listed every two hours. These data are plotted in Figure 4. Initial erratic movement of the gages is attributed to snow resettlement after gage installation. 

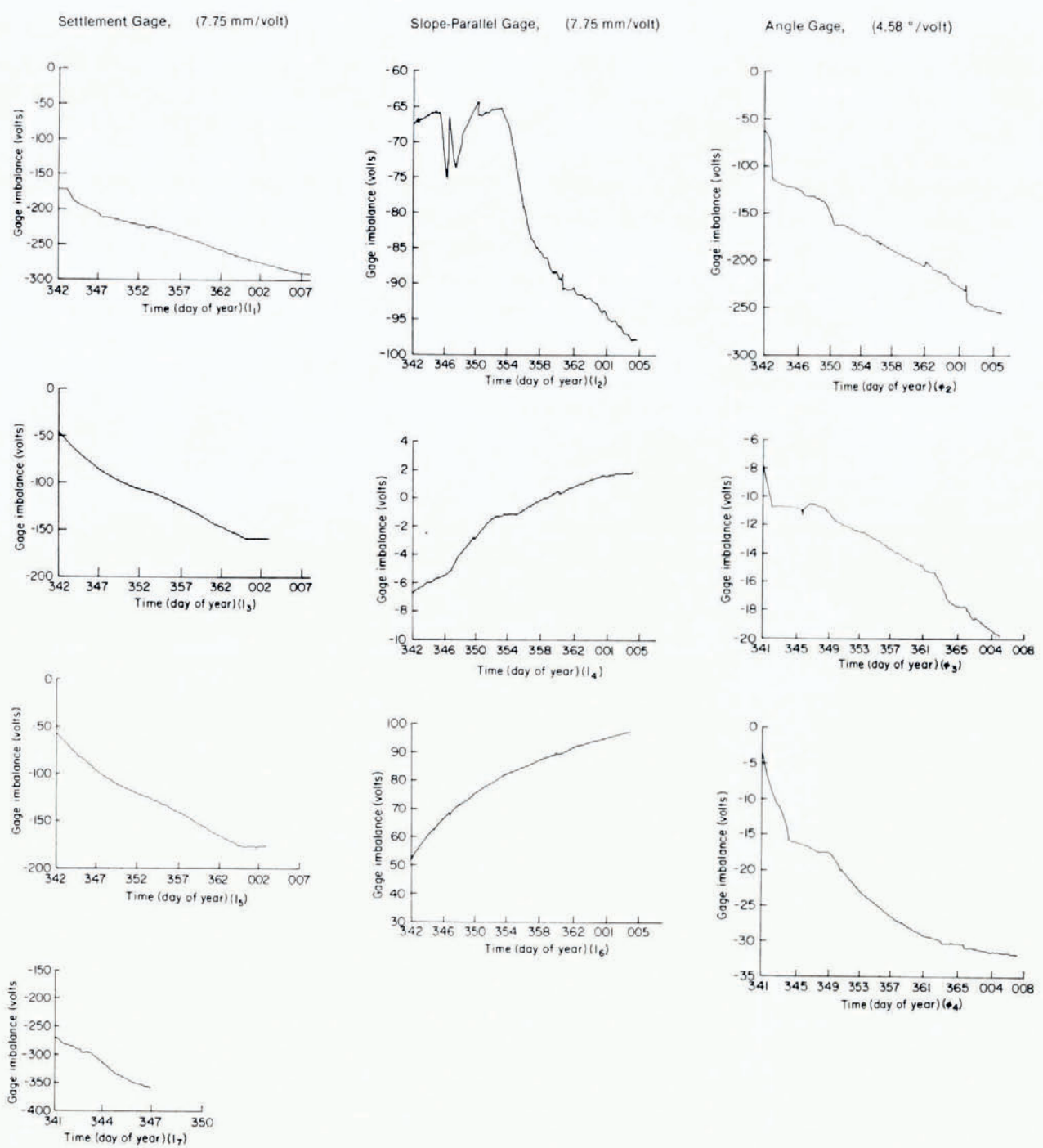

Fig. 4. Linear and angle transducer response curves for the ten gages of the bridge array from day 34I, 1972, to day $005,1973$.

The slope geometry was determined by a transit survey using a meter stick as a rod. The confirmed accuracy of the survey is $\pm 50 \mathrm{~mm}$. The snow-pack geometry was monitored by means of snow cores taken with a Federal snow sampler. The cores were supplemented by snow pits. A compromise was necessary between obtaining accurate data on the geometry and causing excessive disturbance to the snow. Also, the type of corer used precluded accurate density measurements of the temperature-gradient snow that occurred at the bottom of the pack.

\section{Analytical and experimental results}

The first time period considered for analysis was day $35^{\circ}$ through $35^{2}$, 1972 . By this time, the erratic behavior associated with installation had subsided, no new snow had fallen, and 
the pack could be considered in a steady state. A set of cores was taken on day 347 and these data were used to establish the parameters of the five-layer model (Fig. 2). Since the samples of the temperature-gradient snow were likely to introduce errors, the densities of the bottom layer were established using Judson's ( 1967 ) climatological data (shaded regions in Fig. 2). It was found that the bottom layers were important in determining the flow of the pack. For this reason, and because the specific weights of the bottom layer were not well known, two additional computer runs were made with the density of the lowest layer varied by $\pm 10 \%$.

The linear deformation rates in $\mathrm{mm} / \mathrm{d}$ and the angular deformation rates in $\mathrm{deg} / \mathrm{d}$ were taken from the two-hourly deformation tabulations. Comparisons between the computed and the measured deformation rates are listed in Table I. Rates of gages $\Delta \Phi_{1}$ and $\Delta l_{7}$ were inoperable at this time. On days 353 to $357,0.53 \mathrm{~m}$ of snow with density I 600 to I $800 \mathrm{~N} \mathrm{~m}^{-3}$ deposited in the experimental area. This period was modeled using the stratigraphy of day 347 with the superposition of two additional layers to represent the new deposition. A comparison of the measured and calculated rates is shown in Table I.

TABle I. Comparison OF EXPERIMENTAL MEASUREd AND ANALYTICALly COMPUTED DEFORMATION RATES AT VARIOUS DAYS OVER THE DURATION OF THE EXPERIMENT

\begin{tabular}{ccc} 
& \multicolumn{2}{c}{$\begin{array}{c}\text { Deformation rates } \\
\text { Days } 350 \text { thru } 352 \\
\text { (mm/d or deg/d) }\end{array}$} \\
Element & Experiment & Analysis \\
$\Delta l_{1}$ & -2.8 & -3.9 \\
$\Delta \Phi_{1}$ & - & 0.32 \\
$\Delta l_{2}$ & -0.2 & 1.3 \\
$\Delta l_{3}$ & -3.7 & -5.0 \\
$\Delta \Phi_{2}$ & 0.33 & 0.35 \\
$\Delta l_{4}$ & 0.5 & 2.6 \\
$\Delta l_{5}$ & -4.6 & -5.8 \\
$\Delta \Phi_{3}$ & 0.18 & 0.49 \\
$\Delta l_{6}$ & 1.6 & 1.5 \\
$\Delta l_{7}$ & - & -0.68 \\
$\Delta \Phi_{4}$ & 0.85 & 0.63
\end{tabular}

\begin{tabular}{|c|c|}
\hline \multicolumn{2}{|c|}{$\begin{array}{l}\text { Deformation rates } \\
\text { Days } 353 \text { thru } 357 \\
(\mathrm{~mm} / \mathrm{d} \text { or } \mathrm{deg} / \mathrm{d})\end{array}$} \\
\hline Experiment & Analysis \\
\hline-4.6 & $\begin{array}{c}-5 \cdot 4 \\
0.4 \mathrm{I}\end{array}$ \\
\hline 0.4 & I.3 \\
\hline $\begin{array}{l}-5.2 \\
0.45\end{array}$ & $\begin{array}{r}-6.8 \\
0.47\end{array}$ \\
\hline 0.2 & 3.9 \\
\hline-5.6 & -7.6 \\
\hline 0.33 & o.68 \\
\hline I. 3 & 5.0 \\
\hline - & -1.0 \\
\hline 0.7 I & 1.04 \\
\hline
\end{tabular}

\begin{tabular}{|c|c|}
\hline \multicolumn{2}{|c|}{$\begin{array}{l}\text { Deformation rates } \\
\text { Days oor thru oo5 } \\
(\mathrm{mm} / \mathrm{d} \text { or } \mathrm{deg} / \mathrm{d})\end{array}$} \\
\hline Experiment & Analysis \\
\hline-2.4 & $\begin{array}{c}-3.9 \\
0.3^{2}\end{array}$ \\
\hline o. I & -0.2 \\
\hline $4.6^{*}$ & -4.6 \\
\hline $0.45^{*}$ & 0.28 \\
\hline 0.1 & I.5 \\
\hline$-5.6^{*}$ & -3.8 \\
\hline $0.33^{*}$ & $0.3^{6}$ \\
\hline 0.6 & I. 7 \\
\hline 一 & $0.5^{\circ}$ \\
\hline $0.71^{*}$ & 0.50 \\
\hline
\end{tabular}

* Extrapolated values.

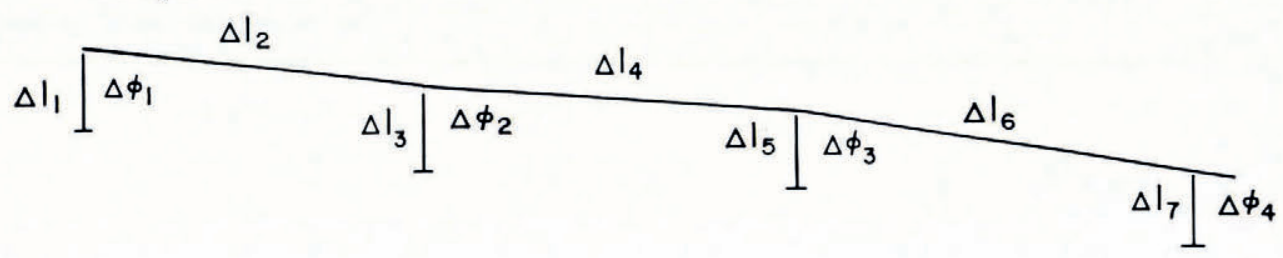

The snow stratigraphy measured on day 005 (Fig. 5) is used to formulate another sevenlayer model for days oo r to 005, 1973. By day oor, over half the gages had reached the limits of their ranges. Extrapolated deformation rates based on the slopes of the curves in Figure 4 were used in these cases.

It became evident that the specific description of the basal layer has a marked effect on the creep response of the entire slope. It should be noted that the basal layer, which varied in vertical depth between 50 and $100 \mathrm{~mm}$, was well developed depth hoar (III-B-2 and III-B-3) during the experimental period. The mechanical properties of this type of snow are virtually unknown. For this reason two computer runs were made with the model of Figure I, but with basal-layer density changed by $+10 \%$ and $-10 \%$. The deformation values obtained are compared with the initial model in Table II. 


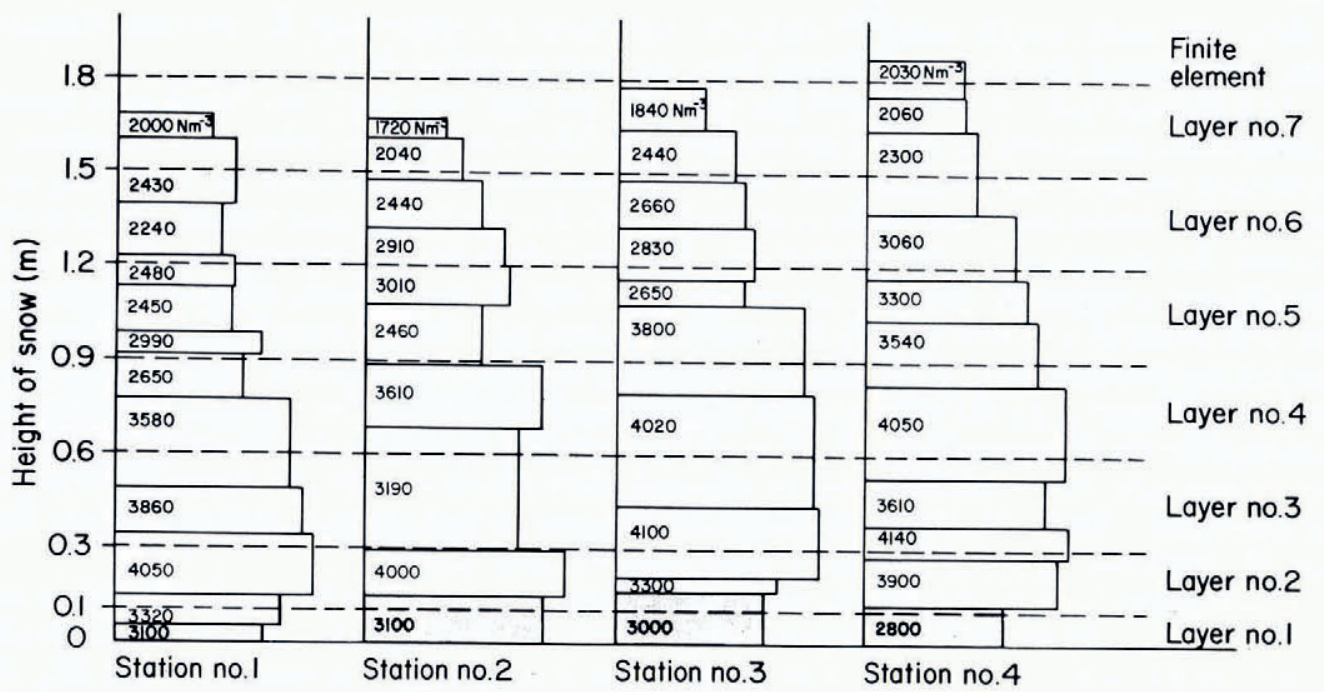

Fig. 5. Specific weight of snow versus height at the four gaging stations, with superimposed levels of finite-element layering as indicated. Data for day 005,1973 .

TABle II. VARIATION IN THE DEFormation RATES FOR A $\pm 10 \%$ VARIATION IN SPECIFIC WEIGHT SPECIFICATION OF THE BASAL LAYER (IOO Mm) OF THE FIVE-LAYER ANALYTICAL MODEL

\begin{tabular}{|c|c|c|c|c|c|}
\hline \multirow[b]{2}{*}{ Element } & \multirow{2}{*}{$\begin{array}{c}\text { Deformation rates } \\
\text { of nominal } \\
\text { analytical model } \\
(\mathrm{mm} / \mathrm{day} \text { or } \mathrm{deg} / \mathrm{d})\end{array}$} & \multicolumn{2}{|c|}{$\begin{array}{c}\text { Deformation rates for } \\
\text { Io \% specific weight increase } \\
\text { of the basal layer (layer number } 1 \text { ) }\end{array}$} & \multicolumn{2}{|c|}{$\begin{array}{c}\text { Deformation rates for } \\
\text { Io\% specific weight decrease } \\
\text { of the basal layer (layer number } 1 \text { ) }\end{array}$} \\
\hline & & $(\mathrm{mm} /$ day or $\mathrm{deg} / \mathrm{d})$ & $\%$ & $(\mathrm{~mm} /$ day or $\mathrm{deg} / \mathrm{d})$ & $\%$ \\
\hline $\begin{array}{l}\Delta l_{1} \\
\Delta \Phi_{1} \\
\Delta l_{2} \\
\Delta l_{3} \\
\Delta \Phi_{2} \\
\Delta l_{4} \\
\Delta l_{5} \\
\Delta \Phi_{3} \\
\Delta l_{6} \\
\Delta l_{7} \\
\Delta \Phi_{4}\end{array}$ & $\begin{array}{c}-3.9 \\
0.32 \\
1.3 \\
-5.0 \\
0.35 \\
2.6 \\
-5.8 \\
0.49 \\
1.5 \\
-6.8 \\
0.63\end{array}$ & $\begin{array}{cc}-3.8 & \\
0.29 \\
-0.1 \\
-4.0 \\
0.27 \\
2.2 \\
-4.7 \\
0.38 \\
1.2 \\
-4.5 \\
0.49 \\
& \text { Avera }\end{array}$ & $\begin{array}{r}-2.6 \\
-9.4 \\
-107.0 \\
-20.0 \\
-23.0 \\
-15.0 \\
-19.0 \\
-22.0 \\
-20.0 \\
-34.0 \\
-22.0 \\
:-29.4\end{array}$ & $\begin{array}{cc}-5.8 \\
0.42 \\
1.4 \\
-7.6 \\
0.46 \\
1.5 \\
-5.6 \\
0.54 \\
3.1 \\
-7.9 \\
0.78 \\
& \\
& \text { Avera }\end{array}$ & $\begin{array}{r}+48.0 \\
+31.0 \\
+7.7 \\
+52.0 \\
+31.0 \\
-42.0 \\
-3.4 \\
+10.0 \\
+107.0 \\
+16.0 \\
+24.0 \\
++28.1\end{array}$ \\
\hline
\end{tabular}

\section{SUMmARY AND CONCLUSIONS}

Comparison of the experimental and analytical deformation rates listed in Tables I and II demonstrates a close order-of-magnitude correspondence. The analytical deformation rates for days $35^{\circ}$ through 353 and 353 through 357 , I972, are larger than the experimental values, showing a more fluid analytical representation than that exhibited by the slope. Much of the discrepancy can be attributed to the problems of defining the basal layer accurately. The strong influence of the basal layer on creep and settlement is demonstrated by the results of the sensitivity analysis shown in Table II. A $\pm 10 \%$ variation in the specific weight of the basal layer results in a $\pm 28 \%$ variation in creep and settlement rates $1.0 \mathrm{~m}$ above the ground in a snow slab averaging $1.2 \mathrm{~m}$ depth. In the analytical model, the viscous properties of normally metamorphosed mid-pack snow of comparable specific weight were used. It is generally believed that higher-density depth hoar, is stiffer than comparable mid-pack snow before failure. This is consistent with the fact that the deformation rates corresponding to the 
$+10 \%$ case more nearly coincide with the experimental values than do the rates deduced from the nominal densities established from the climatological data.

The deformation rates computed for days oor through 005, I 973 , are based on a second stratification measurement carried out on day 005. The analytical model verifies the observed trend that the slab was stabilizing because of the densification of lower layers. It is likely that this densification process was proceeding continually throughout the experiment, which would account for the greater total discrepancy between analysis and experiment on days 353 through 357 , compared with days $35^{\circ}$ to $35^{2}$. For both of these periods, the material description was based on the stratigraphy determined on day 347 without introducing any factor to account for densification. A densification process is not in strong evidence in the deformation histories of Figure 4, so the effect cannot be considered dominant. The apparent densification suggested by the history of gage $\Phi_{4}$ (Fig. 4) is an artefact caused by the bottoming of gage $l_{7}$ during day 346 . After this date gage $\Phi_{4}$ changed more slowly since it also reacted to differential settlement. Similar behavior pertains to other gages on days oo I through 005 , as more than half the gages had reached the end of their travel by day oor.

Gross adjustment of the specific weight of the entire basal layer by some factor does not eliminate all of the discrepancy between experimental and analytical results. Of particular interest is the lack of correlation between the slope-parallel gages, denoted by rates $\Delta l_{2}, \Delta l_{4}$ and $\Delta l_{6}$. The creep rates reflect changes in lengths of the material fibers parallel to the slope. For an infinite uniform slope these rates are, in fact, zero, so that material inhomogenity and irregular geometry must contribute to the non-zero values. Due to the extreme sensitivity of the creep to the character of the basal layers, outcrops with dimensions in excess of the basal layer thickness $(\approx$ roo $\mathrm{mm}$ ) could have a significant effect on local flow rates, particularly on the slope-parallel strain-rate. In the analytical modeling a smooth ground surface was assumed.

A second possible cause of the discrepancies is that the stratification measurements made at the four gage stations are not close enough to detect all of the local lens depositions that are numerous in the test field due to wind-induced deposition. Whereas, for stress prediction, detailed terrain specification and material stratification are secondary effects, the same is not the case if one wishes to obtain a detailed model of the deformation states. It was observed that in smoothing the distribution of specific weight in a particular layer, significant changes in deformation rates occurred also. Thus it is to be expected that local lenses of high or low density will influence local deformation rates.

This discussion by no means exhausts plausible explanations for local perturbations between experiment and analysis. However, the overriding point from these results is that general correspondence is established between experiment and analysis of a typical alpine slope. The dominant slope-deformation characteristic is that flow is sensitive to the presence of a well-defined weak layer, and accurate modeling is dependent on explicit definition of the flow properties of this type of layer. A second important conclusion is that the credibility of supportive analyses of slope geometries is established, if due regard is given to the determination of material stratigraphy. Based, in part, on these findings, the suggestion is made that correlating slope analyses should be considered as a viable tool in establishing and studying characteristics of snow-avalanche mechanics.

\section{REFERENCES}

Goudreau, G. L., and others. 1967. Plane and axisymmetric finite element analysis of locally orthotropic elastic solids and orthotropic shells, by G. L. Goudreau, R. E. Nickell and R. S. Dunham. Berkeley, University of California. Structural Engineering Laboratory. (Structures and Materials Research. Report No. 67-15.)

Haefeli, R. I 963 . Stress transformations, tensile strengths and rupture processes of the snow cover. (In Kingery, W. D., ed. Ice and snow; properties, processes, and applications: proceedings of a conference held at the Massachusetts Institute of Technology, February I 2-I6, 1962. Cambridge, Mass., M.I.T. Press, p. 560-75.) 
Judson, A. 1967. Snow cover and avalanches in the high alpine zone of western United States. (In Ōura, H., ed. Physics of snow and ice: international conference on low temperature science. . . Ig66. . . Proceedings, Vol. $\mathrm{I}, \mathrm{Pt} .2$. [Sapporo], Institute of Low Temperature Science, Hokkaido University, p. i ${ }_{5}{ }_{1}-68$.)

Lang, T. E., and Brown, R. L. [1975.] Stress concentration in sloping snowpack from geometric imperfections. [Union Géodésique et Géophysique Internationale. Association Internationale des Sciences Hydrologiques. Commission des Neiges et Glaces.] Symposium. Mécanique de la neige. Actes du colloque de Grindelwald, avril I974, p. 3 I I-20. (IAHSAISH Publication No. I 14.)

Perla, R. I. 1971. The slab avalanche. Alta, Utah, U.S. Dept. of Agriculture. Forest Service. (Alta Avalanche Study Center Report No. roo.)

Salm, B. [1975.] A constitutive equation for creeping snow. [Union Géodésique et Géophysique Internationale. Association Internationale des Sciences Hydrologiques. Commission des Neiges et Glaces.] Symposium. Mécaniuqe de la neige. Actes du colloque de Grindelwald, avril 1974, p. 222-35. (IAHS-AISH Publication No. I I 4.)

Shinojima, K. 1967 . Study on the visco-elastic deformation of deposited snow. (In Oura, H., ed. Physics of snow and ice: international conference on low temperature science. . . I966. . . . Proceedings, Vol. I, Pt. 2. [Sapporo], Institute of Low Temperature Science, Hokkaido University, p. 875-907.)

Smith, F. W., and Curtis, J. O. [1975.] Stress analysis and failure prediction in avalanche snowpacks. [Union Géodésique et Géophysique Internationale. Association Internationale des Sciences Hydrologiques. Commission des Neiges et Glaces.] Symposium. Mécanique de la neige. Actes du colloque de Grindelwald, avril 1974, p. 332-40. (IAHS-AISH Publication No. 1 14.$)$

Sommerfeld, R. A. 1974. A Weibull prediction of the tensile strength-volume relationship of snow. Fournal of Geophysical Research, Vol. 79, No. 23, p. 3353-56.

Sommerfeld, R. A. [1975.] Continuous measurements of deformations on an avalanche slope. [Union Géodésique et Géophysique Internationale. Association Internationale des Sciences Hydrologiques. Commission des Neiges et Glaces.] Symposium. Mécanique de la neige. Actes du colloque de Grindelwald, avril 1974, p. 293-97. (IAHS-AISH Publication No. 114 .)

\section{DISGUSSION}

D. M. McClung: Can you comment on the effect of snow creep around the housing of the strain gauges on the actual deformation measurements?

R. A. Sommerfeld: Large pieces of wire mesh were placed at the ends of the gauges to eliminate extremely local creep effects.

MaClung: How do you choose the values of the moduli in your finite-element calculations?

T. E. LANG: The work of Shinojima on the visco-elastic response of snow under low creep rates was coupled with work by Brown and Lang and by Salm to produce a nominal model for the snow as a function of density. 